\title{
Teachers' perspectives on nutrition education in boys' public high schools in Riyadh, Saudi Arabia
}

\author{
Khalid Aldubayan ${ }^{1}$
}

${ }^{1}$ Department of Community Health Sciences, College of Applied Medical Sciences, King Saud University, Riyadh, Saudi Arabia (Correspondence to: Khalid Aldubayan: kaldubayan@ksu.edu.sa).

\begin{abstract}
Background: Nutrition education in school may positively affect students' eating behaviour. Teachers need to be empowered to teach nutrition, but no studies have investigated teachers' views on this topic in Saudi Arabia.

Aims: This study investigated the perspective of teachers on nutrition education and their confidence in teaching it in boys' public high schools in Riyadh, Saudi Arabia.

Methods: In 2015, 80 boys' public high schools were randomly selected from four areas of Riyadh, and 80 teachers (biological sciences, physical education and health education teachers) were interviewed using a validated questionnaire. A Fisher exact test was run to test the relationship between teachers' perspective and confidence level, and their subject taught.

Results: Almost all the teachers (98\%) agreed that the health education curriculum should be taught as a core subject for high-school students. Most of the teachers (89\%) were interested in teaching nutrition. However, $64 \%$ indicated that they did not have adequate nutrition curricular materials and $70 \%$ considered that they had not received adequate training on nutrition education. However, $89 \%$ were confident that their students would be interested in nutrition and that such education would change their dietary behaviour. Science and health education teachers were more interested in teaching nutrition and were more confident in their ability to do so than physical education teachers $(P<0.05)$.
\end{abstract}

Conclusions: Most of the teachers were interested in teaching nutrition but barriers existed, such as lack of training and teaching materials, which affected teachers' confidence in delivering nutrition education in their curricula.

Keywords: diet, health education, schools, teachers, Saudi Arabia

Citation: Aldubayan K. Teachers' perspectives on nutrition education in boys' public high schools in Riyadh, Saudi Arabia. East Mediterr Health J.

2020;26(2):170-175. https://doi.org/10.26719/2020.26.2.170

Received: 06/11/17; accepted: 16/04/18

Copyright (c) World Health Organization (WHO) 2020. Open Access. Some rights reserved. This work is available under the CC BY-NC-SA 3.o IGO license (https://creativecommons.org/licenses/by-nc-sa/3.o/igo).

\section{Introduction}

The prevalence of childhood obesity has been growing on a global scale. It is steadily affecting many low- and middle-income countries, particularly in urban areas (1). In 2010, a national Saudi Arabian study recruited 9317 Saudi Arabian children aged five to 18 years from primary health care centres and measured their weight and height (2). The study found that $23.1 \%$ of the children were overweight and $9.3 \%$ were obese.

Obesity is considered a complex disease because several factors can increase its risk. Nutrition education and knowledge is one factor as it can influence food choices. Four cross-sectional studies investigated the effect of dietary behaviour on the weight and health of Saudi Arabian school students (3-6). They all found a negative relationship between educational level and the consumption of processed and energy-dense foods. These studies recommended providing sustainable nutrition education programmes for both students and their parents. They also suggest that policy-makers target schools by including nutrition-related topics in school the curriculum.

In Saudi Arabia, only a few studies have examined students' knowledge about nutrition and eating habits.
In $\mathrm{Al}$-Khobar, in the eastern region, most teenagers were found to have little knowledge about energy-dense foods, such as foods high in saturated fat, and nutrientdense foods, such as those rich in fibre (7). The students indicated that their main source of nutrition information was the media, and their least likely source was primary health care centres (7). In Jeddah, in the western region, women's knowledge of food groups correlated negatively with their education level (8). The study also found a difference between women's food preferences and food group knowledge, especially on fruits, vegetables, dairy products and fat consumption (8). Studies conducted in central, eastern and western regions of Saudi Arabia found a trend among adolescents of skipping breakfast and consuming more foods high in sugar and fat rather than fibre and nutrient-dense foods such as fruits and vegetables (4,9-12). In Riyadh, in the central region, the mean intake per week of fruits and vegetables among adolescents aged 14-19 years was reported to be 2.82 and 3.79 respectively (9). In addition, the mean intake per week of sugar-sweetened drinks and sweets was 4.74 and 3.62 respectively. Another study in Riyadh showed that only $0.99 \%$ of girls aged $12-17$ years liked to eating fruits and vegetables, while $36.63 \%$ and $39.6 \%$ of them preferred chocolate and chips respectively (11). Therefore, nutrition 
education in schools could be an effective tool to increase students' knowledge about healthy and unhealthy foods, which may improve their dietary behaviour.

Health education may positively affect people's lifestyle. As far as we know, no experimental studies have been conducted on young people to test this hypothesis in Saudi Arabia. However, a study conducted in Al-Qassim province in Saudi Arabia showed that health education sessions at primary health care centres increased consumption of fish and fresh vegetables among adults (13). In addition, after the health education sessions, participants were more likely to exercise and less likely to smoke (13). Similar positive effects of health education may also be found with young people. A study conducted in the United States of America suggests that empowering teachers could positively affect students' health outcomes (14). This can be through increasing teachers' self-efficacy for delivering nutrition education (14). Therefore, having teachers assigned for health or/ and nutrition education as role models is essential. In Saudi Arabia, nutrition is taught as part of an elective health education curriculum. In addition, science and physical education teachers may teach some topics on nutrition.

This study aimed investigate the perspective of teachers (science, health education and physical education teachers) about nutrition education and their confidence in teaching nutrition in public high schools for boys in Riyadh, Saudi Arabia.

\section{Methods}

This study was conducted in 80 boys' public high schools in Riyadh city in October 2015: 20 schools each were randomly selected from the north, south, east and west parts of the city. Riyadh has 120 boys' public high schools, so our sample represents $66.7 \%$ of the total. With this sample size and $95 \%$ confidence interval, the margin of error would be $6 \%$. Ethical approval to conduct the study was obtained from the Human Research Protection Program at Texas Tech University, United States of America. The teachers gave their verbal consent to participate.

Two research assistants were trained by the lead investigator to collect data. We approached the principals of the schools and asked them to nominate teachers who taught nutrition within the subject they taught. We then contacted the teachers and selected one who was willing to participate in the study from each school. Thus, 80 teachers from the selected schools were interviewed using a questionnaire about their perception of nutrition education and their confidence in delivering nutrition education to students. The questionnaire was designed from valid questionnaires used in a previous study (15). Some questions in the questionnaire were included in order to be relevant to the Saudi Arabian dietary guidelines. The questionnaire was pretested for face validity. The teachers' perception and confidence level about nutrition education were measured using a fourpoint Likert scale which range from strongly disagree or not at all confident to strongly agree or very confident.

SPSS, version 22 software was used to analyse the results. The Fisher exact test was used to test differences between teachers' perspective and confidence level and their demographic variables. The Fisher exact test was used to test the relationship between teachers' perspectives and confidence levels, and their main subject taught (sciences, health education and physical education). A P-value less than 0.05 was considered statistically significant.

\section{Results}

A total of 80 teachers from 80 schools completed the questionnaire. Demographic characteristics of the teachers are shown in Table 1. Most of the teacher were aged between 30 and 40 years $(61 \%)$ and had a bachelor's degree $(86 \%)$. Almost half $(49 \%)$ of the teachers taught biological sciences, $33 \%$ were physical education teachers and $19 \%$ were health education teachers. Almost two third of the teachers $(65 \%)$ had teaching experience of more than six years. However, all the health education teachers (15 teachers) had less than three years' experience because the health education curriculum, designed by the Saudi Arabian Ministry of Education, had been newly introduced in boys' public high schools. The health education curriculum was taught in 19\% of the selected schools.

About three quarters $(74 \%)$ of the teachers reported that they taught nutrition in their classes. Of those who taught nutrition, $27 \%$ taught it in their classes every day, $24 \%$ taught it weekly and $19 \%$ every two weeks, while $5 \%$ taught nutrition in their classes once a semester, $6 \%$ once

\begin{tabular}{|c|c|}
\hline Characteristic & No. $(\%)(n=80)$ \\
\hline \multicolumn{2}{|l|}{ Age (years) } \\
\hline$<30$ & $6(8)$ \\
\hline $30-40$ & $49(61)$ \\
\hline $41-50$ & $24(30)$ \\
\hline$>50$ & $1(1)$ \\
\hline \multicolumn{2}{|l|}{ Education level } \\
\hline Bachelor's degree & $69(86)$ \\
\hline Diploma & $5(6)$ \\
\hline Master's degree & $6(8)$ \\
\hline \multicolumn{2}{|l|}{ Main subject taught } \\
\hline Biological sciences & $39(49)$ \\
\hline Physical education & $26(33)$ \\
\hline Health education & $15(19)$ \\
\hline \multicolumn{2}{|l|}{ Years of experience } \\
\hline$<3$ & $20(25)$ \\
\hline 35 & $8(10)$ \\
\hline $6-10$ & $15(19)$ \\
\hline $11-15$ & $17(21)$ \\
\hline$>15$ & $20(25)$ \\
\hline
\end{tabular}


a month, $4 \%$ once per year and $15 \%$ taught it when needed. The teachers reported that they taught the following subjects: micro- and macro-nutrients (59\%), food pyramid (23\%) and diet-related diseases (19\%).

With regard to teachers' perception of nutrition education, $89 \%$ of the teachers were interested in teaching nutrition and $98 \%$ agreed that a health education curriculum, which include topics on nutrition, should be taught as a core subject for students. However, $64 \%$ of the teachers reported that adequate nutrition curricular materials were not available to them and $80 \%$ said that the materials available were not appealing to their students as they were outdated. Almost three quarters of the teachers $(71 \%)$ were interested in arranging nutrition activities with nutrition specialists. Most of the teachers $(78 \%)$ reported that the school canteen did not offer healthy food for students. Most of the teachers (73\%) were aware of the American food pyramid, but only $36 \%$ were aware of the Saudi Arabian food palm, and 38\% were aware of the dietary guidelines produced by the Saudi Arabian Ministry of Health.

As regards teachers' confidence level about nutrition education, $70 \%$ of the teachers reported that overall they were not confident in teaching nutrition because they had not received adequate training. Just over half of the teachers $(52 \%)$ reported that they were confident in teaching the American food pyramid and the Saudi Arabian food palm, and $40 \%$ were confident in teaching the food groups. Half of the teachers (50\%) reported that they were confident in teaching the dietary guidelines for Saudi Arabians, and 73\% were confident in teaching their students about eating a balanced diet. The majority of the teachers $(86 \%)$ were confident in teaching about foods high in fat, sugar and salt, and $80 \%$ were confident in teaching their students to reduce their intake of these kinds of food. About two thirds of the teachers (64\%) were confident in teaching about foods high in fibre, vitamins, and minerals, and $85 \%$ were confident in teaching their students to increase their consumption of these kinds of food. Most of the teachers $(86 \%)$ were confident in raising their students' interest about nutrition and 89\% were confident that their students would be interested in nutrition after teaching it. The majority of the teachers $(84 \%)$ were confident that teaching nutrition would increase their students' knowledge and $89 \%$ were confident that teaching nutrition would improve their students' eating behaviour.

There was a statistically significant relationship between teachers' perspectives of teaching nutrition (based on four statements) and their main subject taught (Table 2) but not for any other statements. In addition, a significant relationship was found between teachers' confidence levels about teaching nutrition (based on four statements) and their main subject taught (Table 3). Overall, science and health education teachers were more interested in teaching nutrition and were more confident in their ability to do so than physical education teachers.

\section{Discussion}

The purpose of this study was to investigate the teachers' perspectives and confidence levels about teaching nutrition in their classes at boys' public high schools in $\mathrm{Ri}$ yadh. The results showed that most of the teachers considered healthy food choices an important nutrition topic and they tried to influence the food choices made by their students. Topics related to food choices such as nutrients in food and the food pyramid were taught by most of the teachers. Therefore, the teachers were confident teaching topics related to food choices. Similar findings were found in a previous study conducted in the United States of America (16). Although the Saudi food palm and dietary guidelines for Saudi Arabians were produced by the Saudi Arabian Ministry of Health in 2012 to be used in nutrition education, few teachers in our study were aware of the Saudi food palm (36\%) and the dietary guideline for Saudis (38\%). Therefore, increasing teachers' awareness of the Saudi food palm and the dietary guideline for Saudis is required.

\begin{tabular}{|c|c|c|c|c|c|c|c|c|c|c|c|c|c|c|c|c|c|c|c|c|}
\hline \multirow[t]{2}{*}{$\begin{array}{l}\text { Main } \\
\text { subject } \\
\text { taught }\end{array}$} & \multicolumn{5}{|c|}{$\begin{array}{c}\text { The students in my class } \\
\text { prefer other subjects to } \\
\text { nutrition }\end{array}$} & \multicolumn{5}{|c|}{$\begin{array}{l}\text { Adequate nutrition } \\
\text { curricular materials are } \\
\text { available to me }\end{array}$} & \multicolumn{5}{|c|}{$\begin{array}{l}\text { I think I have had adequate } \\
\text { training from qualified } \\
\text { people on nutrition } \\
\text { education }\end{array}$} & \multicolumn{5}{|c|}{$\begin{array}{c}\text { I am aware of the food } \\
\text { pyramid }\end{array}$} \\
\hline & SA & $\mathbf{A}$ & D & SD & $\begin{array}{l}\text { Fisher } \\
\text { exact } \\
\text { test }\end{array}$ & SA & $\mathbf{A}$ & D & SD & $\begin{array}{l}\text { Fisher } \\
\text { exact } \\
\text { test }\end{array}$ & SA & $\mathbf{A}$ & D & SD & $\begin{array}{l}\text { Fisher } \\
\text { exact } \\
\text { test }\end{array}$ & SA & $\mathbf{A}$ & D & SD & $\begin{array}{c}\text { Fisher } \\
\text { exact } \\
\text { test }\end{array}$ \\
\hline $\begin{array}{l}\text { Biological } \\
\text { sciences }\end{array}$ & 2 & 17 & 15 & 5 & $\begin{array}{l}12.9 \\
P= \\
0.024\end{array}$ & 3 & 11 & 20 & 5 & $\begin{array}{l}25.5 \\
P< \\
0.001\end{array}$ & 2 & 11 & 23 & 3 & $\begin{array}{l}12.9 \\
P= \\
0.024\end{array}$ & 8 & 27 & 2 & 2 & $\begin{array}{c}24.1 \\
P< \\
0.001\end{array}$ \\
\hline $\begin{array}{l}\text { Physical } \\
\text { education }\end{array}$ & 3 & 14 & 9 & 0 & & 2 & 1 & 17 & 6 & & 2 & 2 & 15 & 7 & & 0 & 10 & 10 & 6 & \\
\hline $\begin{array}{l}\text { Health } \\
\text { education }\end{array}$ & 0 & 2 & 11 & 2 & & 0 & 12 & 2 & 1 & & 0 & 7 & 8 & 0 & & 1 & 12 & 2 & 0 & \\
\hline
\end{tabular}

SA: strongly agree; A: agree, D: disagree, SD: strongly disagree. 


\begin{tabular}{|c|c|c|c|c|c|c|c|c|c|c|c|c|c|c|c|c|c|c|c|c|}
\hline \multirow[t]{2}{*}{$\begin{array}{l}\text { Main } \\
\text { subject } \\
\text { taught }\end{array}$} & \multicolumn{5}{|c|}{$\begin{array}{l}\text { I understand nutrition } \\
\text { concepts well enough to } \\
\text { teach them to my students }\end{array}$} & \multicolumn{5}{|c|}{$\begin{array}{c}\text { I can do a good job teaching } \\
\text { students what the food } \\
\text { pyramid is }\end{array}$} & \multicolumn{5}{|c|}{$\begin{array}{l}\text { I can do a good job teaching } \\
\text { students about reducing fat, } \\
\text { sugar, and salt in their diet }\end{array}$} & \multicolumn{5}{|c|}{$\begin{array}{l}\text { I can do a good job teaching } \\
\text { students about increasing } \\
\text { fruits, vegetables, and grains } \\
\text { in their diet }\end{array}$} \\
\hline & VC & C & NC & NAAC & $\begin{array}{c}\text { Fisher } \\
\text { exact } \\
\text { test }\end{array}$ & VC & C & NC & NAAC & $\begin{array}{c}\text { Fisher } \\
\text { exact } \\
\text { test }\end{array}$ & VC & C & NC & NAAC & $\begin{array}{l}\text { Fisher } \\
\text { exact } \\
\text { test }\end{array}$ & VC & C & NC & NAAC & $\begin{array}{c}\text { Fisher } \\
\text { exact } \\
\text { test }\end{array}$ \\
\hline $\begin{array}{l}\text { Biological } \\
\text { sciences }\end{array}$ & 4 & 19 & 14 & 2 & $\begin{array}{l}18.7 \\
P= \\
0.002\end{array}$ & 7 & 20 & 11 & 1 & $\begin{array}{c}21.8 \\
P< \\
0.001\end{array}$ & 13 & 25 & 1 & 0 & $\begin{array}{c}34.1 \\
P< \\
0.001\end{array}$ & 17 & 21 & 1 & 0 & $\begin{array}{c}27.3 \\
P< \\
0.001\end{array}$ \\
\hline $\begin{array}{l}\text { Physical } \\
\text { education }\end{array}$ & 0 & 6 & 14 & 6 & & 1 & 3 & 19 & 3 & & 1 & 10 & 14 & 1 & & 1 & 14 & 10 & 1 & \\
\hline $\begin{array}{l}\text { Health } \\
\text { education }\end{array}$ & 1 & 12 & 2 & 0 & & 2 & 9 & 4 & 0 & & 3 & 12 & 0 & 0 & & 4 & 11 & 0 & 0 & \\
\hline
\end{tabular}

VC: very confident, C: confident, NC: not confident, NAAC: not at all confident.

The present study found that most of the teachers (89\%) were interested in teaching nutrition and tried to incorporate nutrition activities in their classes. These elements indicated that teachers in boys' public high schools in Saudi Arabia could be motivated to teach nutrition. On the other hand, our study showed that lack of teaching materials and lack of training could be barriers to teaching nutrition. Almost two third of teachers reported that adequate nutrition materials were not available, and $80 \%$ reported the material available was not appealing to their students. Most of the teachers reported that healthy foods were not available in their school canteen. Most teachers (70\%) were not confident in teaching nutrition as they had not received adequate training. The aforementioned motivational elements and barriers were identified by two previous qualitative studies conducted in United States of America and South Africa $(17,18)$. The researchers found that the schools environment and teachers' perceptions play an important role in addressing issues that weaken the influence of nutrition education on students' eating habits.

With regard to the relationship between teachers' perspectives and confidence levels, and the main subject they taught, science teachers and health education teachers had more a positive perspective and greater confidence about teaching nutrition compared with physical education teachers. However, the present study showed that science teachers and health education teachers reported that they received more training and understood the concepts well enough to teach them compared with physical education teachers. Together with an earlier American study, these results indicate that adequate training on nutrition and a good knowledge of the subject will increase teachers' confidence levels (16).

In conclusion, as far as we know, this study is the first to investigate the perceptions and confidence levels of teachers in boys' public high schools in Saudi Arabia. Because of the small sample size, the results cannot be generalized beyond boys' public high schools in Riyadh, Saudi Arabia. The study found some motivational issues and barriers to teaching nutrition among the teachers, and further qualitative studies are required to investigate these issues further among teachers in Saudi Arabia. The present study found that the health education curriculum was newly taught in boys' public high schools as all health education teachers had less than three years' experience. Tailored questionnaires on the new curriculum should be developed to assess its usefulness, and focus group interviews conducted with teachers to get their insight on the new curriculum.

Funding: None.

Competing interests: None declared.

\section{Points de vue des enseignants sur l'éducation et l'enseignement en matière de la nutrition dans les écoles secondaires publiques de garçons à Riyadh (Arabie saoudite)}

\section{Résumé}

Contexte : L'éducation nutritionnelle à l'école peut avoir un effet positif sur le comportement alimentaire des élèves. Les enseignants devraient être habilités à dispenser un enseignement sur la nutrition, mais aucune étude ne s'est intéressée à leurs points de vue concernant ce sujet en Arabie saoudite.

Objectifs : La présente étude s'est intéressée au point de vue des enseignants sur l'éducation nutritionnelle et à leur degré de confiance pour enseigner la nutrition dans les écoles secondaires publiques de garçons à Riyadh.

Méthodes : En 2015, 80 écoles secondaires publiques de garçons ont été sélectionnées aléatoirement dans quatre secteurs de Riyadh, et 80 enseignants (biologie, éducation physique et éducation sanitaire) ont été interrogés au moyen d'un 
questionnaire validé. Un test exact de Fisher a été réalisé pour évaluer la relation entre le point de vue et le niveau de confiance des enseignants, et la matière enseignée.

Résultats : Presque tous les enseignants (98\%) s'accordaient pour affirmer que le programme d'éducation sanitaire devrait être enseigné en tant que matière principale aux élèves du secondaire. La plupart des enseignants (89\%) étaient intéressés par l'enseignement de la nutrition. Cependant, $64 \%$ d'entre eux ont indiqué ne pas posséder les supports adéquats pour dispenser les programmes sur la nutrition et $70 \%$ considéraient ne pas avoir reçu la formation adéquate en matière d'éducation nutritionnelle. Par ailleurs, 89 \% étaient certains que leurs élèves s'intéresseraient à la nutrition et qu'une éducation nutritionnelle modifierait le comportement alimentaire de ces derniers. Les enseignants en sciences et en éducation sanitaire étaient davantage intéressés par l'enseignement de la nutrition et plus confiants en leur capacité d'y parvenir que les enseignants en éducation physique $(p<0,05)$.

Conclusions : La plupart des enseignants étaient intéressés par l'enseignement de la nutrition, tout en notant des obstacles tels que le manque de formation et de supports d'enseignement, à l'origine d'une baisse de leur niveau de confiance pour intégrer l'éducation nutritionnelle à leurs programmes.

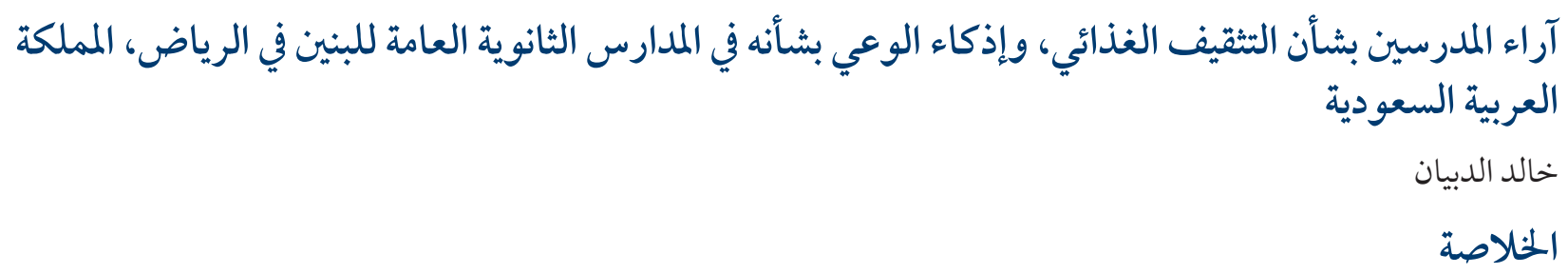

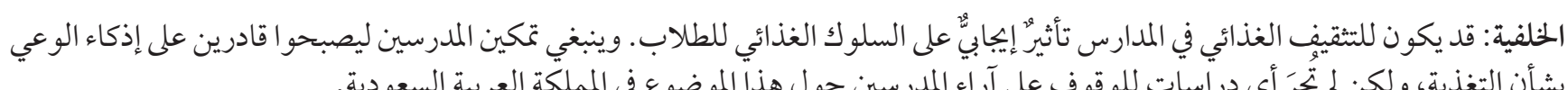
الأهداف: تناولت هذه الدراسة بالبحث رأي المدرسين بشأن التثقيف الغذائي وثقتهم في أنهم يستطيعون إذكاء الوعي بشأنه في المدارس الثانوية

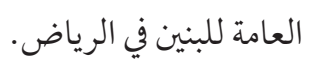

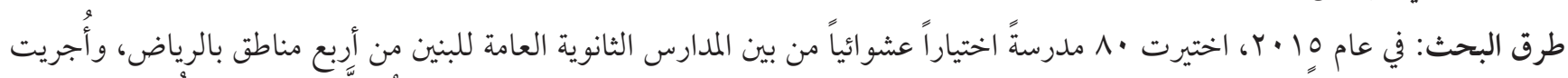

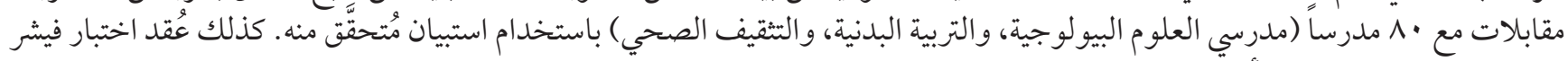

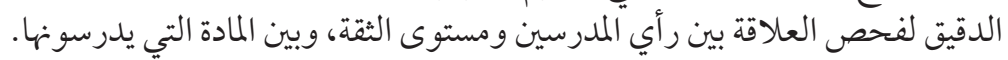

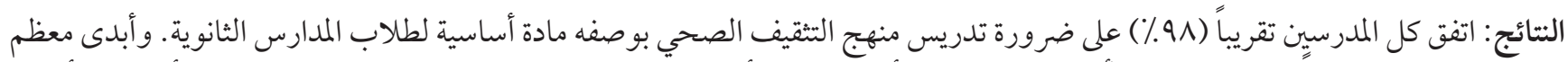

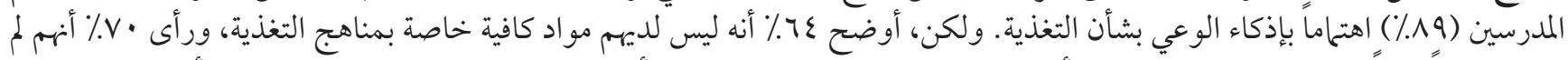

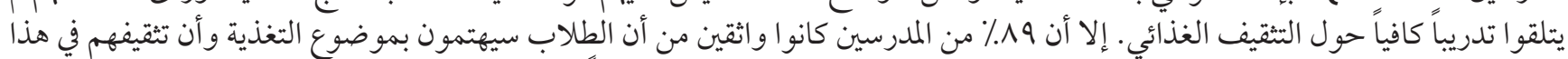

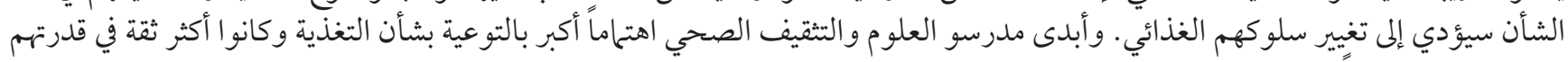

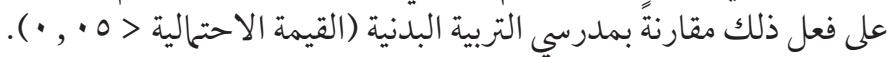

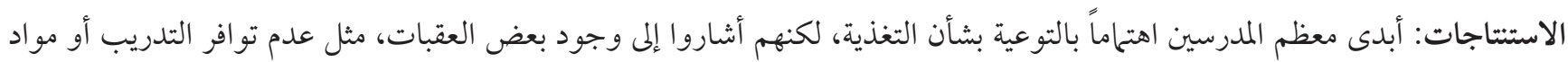

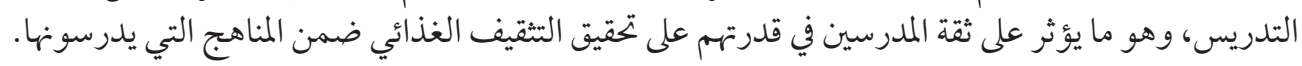

\section{References}

1. Population-based approaches to childhood obesity prevention. Geneva: World Health Organization; 2012

2. El Mouzan MI, Foster PJ, Al Herbish AS, Al Salloum AA, Al Omer AA, Qurachi MM, et al. Prevalence of overweight and obesity in Saudi children and adolescents. Ann Saudi Med. 2010;30(3):203-8. https://doi.org/10.4103/0256-4947.62833

3. Al-Saeed WY, Al-Dawood KM, Bukhari IA, Bahnassy A. Prevalence and socioeconomic risk factors of obesity among urban female students in Al-Khobar city, Eastern Saudi Arabia, 2003. Obes Rev. 2007;8(2):93-9. https://doi.org/10.1111/j.1467789X.2006.00287.X

4. Amin TT, Al-Sultan AI, Ali A. Overweight and obesity and their relation to dietary habits and socio-demographic characteristics among male primary school children in Al-Hassa, Kingdom of Saudi Arabia. Eur J Nutr. 2008;47(6):310-8. https://doi.org/10.1007/ s00394-008-0727-6

5. Farghaly NF, Ghazali BM, Al-Wabel HM, Sadek AA, Abbag FI. Life style and nutrition and their impact on health of Saudi school students in Abha, Southwestern region of Saudi Arabia. Saudi Med J. 2007;28(3):415-21.

6. Mahfouz AA, Shatoor AS, Khan MY, Daffalla AA, Mostafa OA, Hassanein MA. Nutrition, physical activity, and gender risks for adolescent obesity in Southwestern Saudi Arabia. Saudi J Gastroenterol. 2011;17(5):318-22. https://doi.org/10.4103/1319-3767.84486 
7. Al-Almaie S. Knowledge of healthy diets among adolescents in eastern Saudi Arabia. Ann Saudi Med. 2005;25(4):294-8. https:// doi.org/10.5144/0256-4947.2005.294

8. Bakhotmah BA. Nutritional knowledge and desire to change of food preferences among Saudi women in Jeddah, Saudi Arabia. Ecol Food Nutr. 2012;51(4):313-28. https://doi.org/10.1080/03670244.2012.691388

9. Al-Hazzaa HM, Abahussain NA, Al-Sobayel HI, Qahwaji DM, Musaiger AO. Physical activity, sedentary behaviors and dietary habits among Saudi adolescents relative to age, gender and region. Int J Behav Nutr Phys Act. 2011;8:140. https://doi. org/10.1186/1479-5868-8-140

10. Al-Hazzaa HM, Abahussain NA, Al-Sobayel HI, Qahwaji DM, Musaiger AO. Lifestyle factors associated with overweight and obesity among Saudi adolescents. BMC Public Health. 2012;12:354. https://doi.org/10.1186/1471-2458-12-354

11. Al-Muammar MN, El-Shafie M, Feroze S. Association between dietary habits and body mass index of adolescent females in intermediate schools in Riyadh, Saudi Arabia. East Mediterr Health J. 2014;20(1):39-45.

12. Collison KS, Zaidi MZ, Subhani SN, Al-Rubeaan K, Shoukri M, Al-Mohanna FA. Sugar-sweetened carbonated beverage consumption correlates with BMI, waist circumference, and poor dietary choices in school children. BMC Public Health. 2010;10:234. https://doi.org/10.1186/1471-2458-10-234

13. Midhet FM, Sharaf FK. Impact of health education on lifestyles in central Saudi Arabia. Saudi Med J. 2011;32(1):71-6.

14. Snelling AM, Ernst J, Belson SI.. Teachers as role models in solving childhood obesity. J Pediatr Biochem. 2013;3(1):55-60. https:// doi.org/10.3233/JPB-120074

15. Murimi M, Colvin J, Liner K, Guin J. Methodology to evaluate outcomes of the team nutrition initiative in schools. Louisiana Tech University; 2006 (http://naldc.nal.usda.gov/download/32793/PDF, accessed 26 June 2019).

16. Murimi MW, Sample AD, Guthrie J, Landry D. Nutrition education in Team Nutrition middle schools: Teachers' perceptions of important topics to be taught and teaching curriculum used. J Child Nutr Manage. 2007;2(31):1-12.

17. Mita SC, Li E, Goodell LS. A qualitative investigation of teachers' information, motivation, and behavioral skills for increasing fruit and vegetable consumption in preschoolers. J Nutr Educ Behav. 2013;45(6):793-9. https://doi.org/10.1016/j.jneb.2013.05.001

18. Kupolati MD, Gericke GJ, MacIntyre UE. Teachers' perceptions of school nutrition education's influence on eating behaviours of learners in the Bronkhorstspruit District. S Afr J Educ. 2015;35(2):1-10. https://doi.org/ 10.15700/saje.v35n2a1049 